\title{
NG2 Glial Cells Provide a Favorable Substrate for Growing Axons
}

\author{
Zhongshu Yang, Ryusuke Suzuki, Stephen B. Daniels, Christopher B. Brunquell, Christopher J. Sala, and \\ Akiko Nishiyama \\ Department of Physiology and Neurobiology, University of Connecticut, Storrs, Connecticut 06269-3156
}

\begin{abstract}
NG2 cells (polydendrocytes) comprise an abundant glial population that is widely and uniformly distributed throughout the developing and mature CNS and are identified by the expression of the NG2 proteoglycan at the cell surface. Although recent electrophysiological studies suggest that they are capable of receiving signals from axon terminals, other studies, based on the finding that the NG2 molecule itself induces growth cone collapse, have led to a widely held speculation that NG2 cells themselves also repel and inhibit growing axons. In this study, we have examined the effects of rat NG2 cells on growing hippocampal and neocortical axons in vitro and in vivo. NG2 cells did not repel growing axons but promoted their growth in vitro, and axonal growth cones formed extensive contacts with NG2 cells both in vitro and in the developing corpus callosum. Punctate immunoreactivity for fibronectin and laminin was found to be colocalized with NG2 on the surface of NG2 cells. Altering the level of cell surface NG2 expression had no effect on the growth-promoting effects of NG2 cells on growing axons. Thus, our study indicates that NG2 cells are not inhibitory to growing axons but provide an adhesive substrate for axonal growth cones and promote their growth even in the presence of elevated levels of the NG2 proteoglycan. These findings suggest a novel role for NG2 cells in facilitating axonal growth during development and regeneration.
\end{abstract}

Key words: NG2; oligodendrocyte progenitor; proteoglycan; growth cone; axon; neurites; fibronectin; laminin

\section{Introduction}

NG2 cells comprise a major glial cell population in the developing and mature mammalian CNS (Nishiyama et al., 2002). They are identified by the expression of the NG2 proteoglycan on the surface. Some NG2 cells differentiate into oligodendrocytes in vitro (Levine and Stallcup, 1987; Stallcup and Beasley, 1987) and in vivo during normal development (Horner et al., 2000; Bu et al., 2004) and in demyelinated lesions (Watanabe et al., 2002), and they downregulate NG2 during terminal differentiation. Thus, NG2 cells are often referred to as oligodendrocyte precursor cells (OPCs). However, even after peak myelination, NG2 cells continue to exist uniformly throughout the gray and white matter of the CNS, at a density comparable with that of mature oligodendrocytes and microglia (Dawson et al., 2003). This is indicative of a physiological role for them in the CNS in addition to generating myelinating oligodendrocytes. To recognize their existence as an

Received 0ct. 5, 2005; revised Feb. 17, 2006; accepted Feb. 23, 2006.

This study was supported by grants from the Wadsworth Foundation and National Institutes of Health (R01NS035136 and R01NS049267). We thank Dr. William Stallcup (Burnham Institute, La Jolla, CA) for rabbit and mouse antibodies to NG2 and rabbit antibody to PDGFR $\alpha$. We thank Dr. Joel Levine (State University of New York, Stony Brook, NY) for rabbit antibody to NG2 and for helpful discussions and suggestions. We also thank Drs. Marie Filbin and Wilfredo Mellado (Hunter College, New York, NY) for MAG-CHO cells. We thank Dr. Joseph LoTurco and Jilin Bai (Department of Physiology and Neurobiology, University of Connecticut, Storrs, (T) for their assistance with in utero electroporation. We thank Dr. Maria Rubio (Department of Physiology and Neurobiology, University of Connecticut, Storrs, (T) for her advice on preembedding immunoelectron microscopy and Dr. Marie Cantino for her help in the Electron Microscopy Facility.

Correspondence should be addressed to Akiko Nishiyama, Department of Physiology and Neurobiology, University of Connecticut, 75 North Eagleville Road, Unit 3156, Storrs, CT 06269-3156. E-mail: akiko.nishiyama@uconn.edu.

D01:10.1523/JNEUROSCI.4247-05.2006

Copyright $\odot 2006$ Society for Neuroscience $\quad 0270-6474 / 06 / 263829-11 \$ 15.00 / 0$ abundant resident population in normal mature brain, we have proposed to use the term polydendrocytes to refer to all CNS parenchymal cells that express NG2 (Nishiyama et al., 2002), a name that reflects their multiprocessed morphology and their lineal relation to oligodendrocytes.

The NG2 molecule belongs to the family of chondroitin sulfate proteoglycans, which are generally known to be repulsive to growing axons (Snow et al., 1990; Oakley and Tosney, 1991; Brittis et al., 1992; Friedlander et al., 1994; Milev et al., 1994; Bradbury et al., 2002; Kantor et al., 2004). NG2 has been shown to inhibit neurite outgrowth from cerebellar granule neurons and dorsal root ganglion neurons (Dou and Levine, 1994) through its core protein (Chen et al., 2002a; Ughrin et al., 2003). Furthermore, NG2 expression is dramatically upregulated in adult lesioned CNS (Levine, 1994; Jones et al., 2002) where axonal regrowth is limited. Thus, it has been widely speculated that NG2 cells, as well as the NG2 molecule, negatively regulate axonal growth in vivo (Fidler et al., 1999; Chen et al., 2002b; Morgenstern et al., 2002) (for review, see Levine et al., 2001), although the neuronal growth-inhibitory effect of NG2 cells has never been directly demonstrated.

There are several recent observations that are not consistent with the notion that NG2 cells are repulsive to growing axons. First, in a regenerating environment after spinal cord injury, successfully regenerating axons were found through a region of densely populated NG2-expressing cells (Jones et al., 2003). Second, there was no difference in the extent of axonal regeneration after spinal cord transection in wild-type and NG2-null mutant mice (de Castro et al., 2005). Finally, electrophysiological studies have revealed that NG2 cells in the hippocampus and cerebellum 
receive glutamatergic "synaptic inputs" (Bergles et al., 2000; Lin et al., 2005), and these findings were supported by ultrastructural demonstration of a presynaptic axon terminals apposed to NG2 cell processes. These phenomena would not be observed if NG2 cells repelled axons. To resolve this paradox, we examined the effects of NG2 cells, rather than the NG2 molecule, on axonal growth. We demonstrate that NG2 cells do not repel but promote axonal growth regardless of the level of NG2 expression.

\section{Materials and Methods}

Antibodies. Rabbit anti-rat NG2 antibodies were obtained from Drs. William Stallcup (Burnham Institute, La Jolla, CA) and Joel Levine (State University of New York, Stony Brook, NY) and were used at 1:2000 dilution. Mouse monoclonal anti-rat NG2 antibodies were obtained from Dr. W. Stallcup and were used at 1:100 dilution. Antibody to phosphorylated neurofilaments (SMI31; 1:200) was obtained from Sternberger Monoclonals (Lutherville, MD). Monoclonal antibodies to bovine glial fibrillary acidic protein (GFAP) (1:1000), human $\beta$-tubulin isotype III (1:200), and laminin (1:200) were obtained from Sigma (St. Louis, MO). Guinea pig anti-glial glutamate transporter (GLAST) antibody (1:200) was obtained from Chemicon (Temecula, CA). Rabbit antihuman fibronectin (1:100) and anti-bovine GFAP antibodies (1:1000) were obtained from DakoCytomation (Carpinteria, CA). Mouse antibody to green fluorescent protein (GFP) (1:200) was obtained from Chemicon. Mouse monoclonal anti-O1 IgM antibodies were prepared from supernatants of $\mathrm{O} 1$ hybridoma cells (obtained from Dr. Steve Pfeiffer, University of Connecticut Health Center, Farmington, CT).

Alexa 488-conjugated and Alexa 594-conjugated secondary antibodies obtained from Invitrogen (Eugene, OR) were used at 1:1000 and 1:200, respectively. Cy3-conjugated secondary antibodies (Jackson ImmunoResearch, West Grove, PA) were used at 1:200. Aminomethylcoumarin acetate-conjugated donkey anti-mouse IgM antibodies (Jackson ImmunoResearch) were used at 1:50.

Cell culture. Purified NG2 cell (OPC) cultures were prepared as previously described (McCarthy and de Vellis, 1980) with some modifications (Yang et al., 2005). Briefly, cerebral cortices from postnatal day 2 (P2) to P4 Sprague Dawley (CD) rats (Charles River Laboratories, Raleigh, NC) were dissected out, minced, and incubated for $15 \mathrm{~min}$ at $37^{\circ} \mathrm{C}$ in minimum essential medium (Invitrogen) containing $0.1 \%$ trypsin (Sigma). The cells were triturated after adding $60 \mu \mathrm{g} / \mathrm{ml}$ DNase I (Sigma) and 5\% fetal bovine serum (FBS) (Invitrogen). Dissociated cells from two to three rats were plated in a $75 \mathrm{~cm}^{2}$ tissue culture flask coated with 100 $\mu \mathrm{g} / \mathrm{ml}$ poly-L-lysine (PLL) (Sigma). Cells were maintained in DMEM containing $10 \% \mathrm{FBS}$ at $37^{\circ} \mathrm{C}$ in humidified air with $5 \% \mathrm{CO}_{2}$. After $10 \mathrm{~d}$, the cells were rinsed three times with culture medium, and the flasks were sealed and shaken at $250 \mathrm{rpm}$ at $37^{\circ} \mathrm{C}$ for $15 \sim 18 \mathrm{~h}$ followed by additional $30 \mathrm{~min}$ of shaking at $350 \mathrm{rpm}$. Detached NG2 cells were collected, preplated to remove microglia, and plated on PLL-coated coverslips. Cells were maintained in Neurobasal medium with B27 supplements (NBM/ B27) (Invitrogen) containing $10 \mathrm{ng} / \mathrm{ml} \mathrm{PDGF}_{\mathrm{AA}}$ (Roche, Indianapolis, IN). Immunocytochemistry revealed that cultures prepared by this method contained $92-95 \%$ NG2 + cells. GFAP + astrocytes and OX $42+$ microglia comprised $5-8 \%$ and $<1 \%$ of the total population, respectively. In addition, the majority of the GFAP+ astrocytes in the OPC culture had the stellar morphology of type 2 astrocytes. Mature oligodendrocyte cultures were generated by further incubating purified NG2 cell cultures for $3 \mathrm{~d}$ in NBM/B27 without $\mathrm{PDGF}_{\mathrm{AA}}$.

To prepare purified astrocytes, $\mathrm{P} 2-\mathrm{P} 4$ cortical cells were dissociated as described above and plated at a density of $1 \times 10^{4} \mathrm{cells} / \mathrm{cm}^{2}$ onto PLLcoated coverslips. Cells were maintained in DMEM containing 10\% FBS until they reached confluence. Cells were then rinsed once with PBS and cultured in fresh NBM/B27 containing $10 \mathrm{ng} / \mathrm{ml} \mathrm{PDGF} \mathrm{AA}_{\text {and }} 10 \mu \mathrm{M}$ cytosine arabinofuranoside for $4-6 \mathrm{~d}$ to remove proliferating NG2 cells. Medium was changed every other day.

For neuron-glial cocultures, hippocampi from P1 rats were dissociated as described above for glial cultures, and $2.5 \times 10^{4}$ cells were plated in the presence of $100 \mu \mathrm{M} \mathrm{L}$-glutamate on PLL-coated coverslips with or without cellular substrates. Cocultures were maintained in NBM/B27 containing $100 \mu \mathrm{M} \mathrm{L}$-glutamate at $37^{\circ} \mathrm{C}$ in $5 \% \mathrm{CO}_{2}$ for $16-18 \mathrm{~h}$ and processed for immunocytochemistry.

$\mathrm{NIH} 3 \mathrm{~T} 3$ fibroblast cells were maintained in DMEM containing 10\% newborn calf serum. They were passaged no more than 10 times before reaching confluence to prevent transformation. Chinese hamster ovary cells expressing myelin-associated glycoprotein (MAG-CHO cells) were kindly provided by Drs. Marie Filbin and Wilfredo Mellado (Hunter College, New York, NY) and were maintained in DMEM containing 10\% FBS and G418 (Invitrogen).

For inverted cultures, neurons were seeded onto PLL-coated coverslips as described above. Thirty minutes after the neurons were seeded, coverslips containing non-neuronal cells were placed inverted in tissue culture inserts (Falcon; pore size, $0.45 \mu \mathrm{m}$ ), and the inserts were placed over the neurons. Standard contacting cocultures were prepared simultaneously for control. The cultures were maintained in $1 \mathrm{ml}$ of Neurobasal medium containing B27 for 16-18 h, after which the neurons were fixed and immunostained for SMI31.

NG2 adenoviral vector. An adenoviral vector containing the entire coding region of the rat NG2 cDNA (Nishiyama et al., 1991) was constructed using the Adeno-X Expression System (Clontech, Mountain View, CA). The resulting virus (Adeno-NG2) was synthesized and packaged in HEK 293 cells (American Type Culture Collection, Manassas, VA), and the titer of the viruses harvested from the second round of amplification was determined. Viral stocks of $\sim 1 \times 10^{8} \mathrm{pfu} / \mathrm{ml}$ were prepared and added to the cultures at a multiplicity of infection (moi) of 2 or 5 .

NG2 small interference RNA construction. Small hairpin RNA [small interference RNA (siRNA)] constructs directed against rat NG2 mRNA were generated using mU6 pro plasmid vector (a gift from Dr. David Turner, University of Michigan, Ann Arbor, MI) as described by Yu et al. (2002). We generated two different NG2 siRNA constructs, both targeting the $3^{\prime}$-untranslated region of the rat NG2 cDNA (NG2_7217hp, $5^{\prime}$-uccucagcucacuuagaccuagagauguucucuaggucuaagugagcugagga- $3^{\prime}$; and NG2_7292hp, 5' -caggauaacauccucgauggaucacugugugauccaucgaggauguuauccug- $3^{\prime}$ ). Mutant forms of both siRNAs were generated by randomly mutating three base pairs in the original constructs (NG2_m7217hp, 5'-uccucaggucaguuacaccuagagauguucucuagguguaacugaccugagga-3'; and NG2_m7292hp, 5'-caggauaagaugcuggauggaucacugugugauccauccagcaucuuauccug- $\left.3^{\prime}\right)$. The plasmid DNA containing the NG2 siRNA species were purified and transfected into purified NG2 cells using Rat Oligodendrocyte Nucleofector kit and Nucleofector II (Amaxa Biosystem, Gaithersburg, MD). Secondary cultures of $1 \times 10^{5}$ NG2 cells that had been treated for $2 \mathrm{~d}$ with $10 \mathrm{ng} / \mathrm{ml}$ PDGF $_{\mathrm{AA}}$ were electroporated with $1 \mu \mathrm{g}$ of the plasmid DNA in $100 \mu \mathrm{l}$ of Nucleofect solution using the O-17 program. Transfected cells were then divided into three $12 \mathrm{~mm}$ coverslips that had been coated with $100 \mu \mathrm{g} / \mathrm{ml}$ PLL and maintained in NBM/B27 and $10 \mathrm{ng} / \mathrm{ml} \mathrm{PDGF}_{\mathrm{AA}}$ for $2 \mathrm{~d}$ before the addition of $\mathrm{P} 1$ hippocampal neurons. In some cases, cells were cotransfected with a control plasmid encoding GFP (pmaxGFP; Amaxa) to identify transfected cells. This method resulted in $40-60 \%$ transfection efficiency. The neurons were analyzed as described above $16 \mathrm{~h}$ after they were added to NG2 cells transfected with the siRNA constructs.

Time lapse analysis. Hippocampal neuron-glial cocultures were prepared as described above and subjected to time-lapse recording $16-24 \mathrm{~h}$ after neurons were added to glial cells. In some experiments, glial cells were labeled with $4 \mu \mathrm{M}$ PKH-26 dye (Sigma) to facilitate their identification in the coculture. Coverslips containing the cocultured cells were secured with vacuum grease on the bottom of a recording chamber (Warner Instruments, Hamden, CT). The chamber was then sealed with a coverslip placed on top, and filled with the Hibernate Medium (BrainBits, Springfield, IL) that had been preequilibrated in the $37^{\circ} \mathrm{C} \mathrm{CO}_{2}$ incubator. The temperature of the chamber was controlled at $35-37^{\circ} \mathrm{C}$ using a channel heater controller (Warner Instruments). The assembled chamber was placed on the microscope stage, and time lapse images were collected through the transmitted light channel with differential interference optics on the Leica (Exton, PA) TCS SP2 confocal system.

Immunocytochemistry. For detecting cell surface antigens, cells were rinsed once in blocking solution [DMEM containing 5\% normal goat serum (NGS)] and incubated in primary antibodies diluted in the blocking solution for $30 \mathrm{~min}$ at room temperature. Cells were then rinsed three 
times in the blocking solution and incubated in the secondary antibodies diluted in the blocking solution for $30 \mathrm{~min}$ at room temperature. After two washes in DMEM and two washes in PBS, cells were then fixed in $4 \%$ paraformaldehyde (PFA) for $15 \mathrm{~min}$ at room temperature, followed by three rinses in PBS, and one rinse in $\mathrm{H}_{2} \mathrm{O}$. Coverslips were then air-dried and mounted in Vectashield containing 4', $6^{\prime}$-diamidino-2-phenylindole (DAPI) (Vector Laboratories, Burlingame, CA).

For intracellular antigens, cells were first fixed with 4\% PFA for 15 min at room temperature, rinsed three times in PBS, and then permeabilized and blocked in 5\% NGS-DMEM containing $0.1 \%$ Triton X-100 before antibody incubation.

Western blot analysis. Purified NG2 cells were infected with adenoNG2 virus at a moi of 2 or 5 and used $2 \mathrm{~d}$ later. Proteins were extracted from the cells in $100 \mu$ l of protein extraction buffer ( $50 \mathrm{~mm}$ Tris- $\mathrm{HCl}, 150$ $\mathrm{mm} \mathrm{NaCl}, 1 \% \mathrm{NP}-40, \mathrm{pH} 8.0$ ) containing $1 \mathrm{~mm}$ phenylmethylsulfonyl fluoride (Sigma) and $10 \mu \mathrm{g} / \mathrm{ml}$ leupeptin (Calbiochem, La Jolla, CA) on ice for $15 \mathrm{~min}$. Some extracts were treated with $0.125 \mathrm{U}$ of chondroitinase $\mathrm{ABC}$ (MP Biomedicals, Aurora, $\mathrm{OH}$ ) at room temperature for an additional $15 \mathrm{~min}$. Extracts were then centrifuged at $15,000 \times g$ for $5 \mathrm{~min}$ at $4^{\circ} \mathrm{C}$ to remove insoluble material, and supernatants were heated at $80^{\circ} \mathrm{C}$ for $10 \mathrm{~min}$ in reducing sample buffer (6\% SDS, $40 \%$ glycerol, and 0.2 $\mathrm{mg} / \mathrm{ml} \mathrm{BPB}$, and $100 \mathrm{~mm}$ DTT in $125 \mathrm{~mm}$ Tris-HCl, $\mathrm{pH}$ 6.8). Samples were electrophoresed through $4-12 \%$ acrylamide gradient gels (Novex; Invitrogen) and transferred to polyvinylidene difluoride membranes. The membranes were incubated in blocking buffer containing $5 \%$ nonfat dry milk (Bio-Rad, Hercules, CA) and $0.5 \mathrm{M} \mathrm{NaCl}$ in 20 mм Tris- $\mathrm{HCl}, \mathrm{pH}$ 7.4 , for $2 \mathrm{~h}$ at room temperature and then incubated in rabbit anti-NG2 antibody (obtained from Dr. W. Stallcup) diluted 1:1000 in the blocking buffer at $4^{\circ} \mathrm{C}$ overnight. The membrane was then incubated in HRPconjugated goat anti-rabbit antibody (Bio-Rad) diluted 1:10,000 in blocking buffer for $1 \mathrm{~h}$ at room temperature, followed by chemiluminescence detection according to the manufacturer's instructions (ECL Detection Reagents; Amersham Biosciences, Piscataway, NJ). The same blot was then blocked, incubated in mouse anti-glyceraldehyde-3-phosphate dehydrogenase (GAPDH) antibody (Chemicon; 1:300), followed by incubation in HRP-conjugated goat anti-mouse antibody (Bio-Rad; $1: 10,000)$ and processed for chemiluminescence detection. For densitometric analysis, the film was scanned at a resolution of $300 \mathrm{dpi}$, and the pixel density of the bands was analyzed using BioQuant software (Nashville, TN).

In utero electroporation and immunohistochemistry. In utero electroporation of plasmid DNA was performed as described (Haas et al., 2001; Bai et al., 2003). Sprague Dawley (CD) rats at $17 \mathrm{~d}$ of gestation were anesthetized by intraperitoneal injection of a mixture of ketamine $(10 \mathrm{mg} / 100 \mathrm{~g}$ body weight) and xylazine ( $1 \mathrm{mg} / 100 \mathrm{~g}$ body weight). Through a longitudinal abdominal incision, uterine horns were exposed, and $1 \mu \mathrm{g}$ of pCA-gapgfpm4 plasmid DNA $(0.5 \mu \mathrm{g} / \mu \mathrm{l})$ (Okada et al., 1999) was microinjected into the lateral ventricle of the embryos. Because cortical neuroblasts that form layers II/III are the predominant dividing cell population at the ventricular surface at embryonic day 17 (E17) (Hicks and D'Amato, 1968), electroporation of the pCA-gapgfpm4 plasmid, driven by the universally active chicken $\beta$-actin promoter and cytomegalovirus enhancer, into the ventricles at this age resulted in strong GFP expression in neurons with minimum labeling of glial cells. pCA-gapgfpm 4 encodes green fluorescent protein that contains the membrane-targeting sequence from GAP43 (Okada et al., 1999). Exponentially decaying voltage pulse $\left(V_{\mathrm{o}}=75 \mathrm{~V}\right)$ was applied across the uterine wall via a pair of capacitor plates. Surgery was performed according to the guidelines established by the Institutional Animal Care and Usage Committee.

Two days after birth, the electroporated rat pups were anesthetized by hypothermia and fixed by transcardiac perfusion with $2 \%$ paraformaldehyde in $0.1 \mathrm{M}$ sodium phosphate buffer containing $0.05 \mathrm{~m}$ lysine and 0.01 M sodium metaperiodate (McLean and Nakane, 1974). Coronal sections $(100 \mu \mathrm{m})$ through the corpus callosum were prepared using a vibratome (Leica, Deerfield, IL) and processed for immunohistochemistry as follows. Sections were permeabilized and blocked in PBS containing $0.1 \%$ Triton X-100 and NGS for $1 \mathrm{~h}$ at room temperature and then incubated in primary antibodies diluted in PBS containing 5\% NGS (PBS-NGS) overnight at $4^{\circ} \mathrm{C}$. After three washes in PBS, the sections were incubated with secondary antibodies diluted in PBS-NGS for $30 \mathrm{~min}$ at room temperature. After three washes in PBS, the sections were picked up onto slides, air-dried, and mounted in the Vectashield.

Image acquisition and data analysis. Wide-field microscopic images were acquired using a Leica DMR upright epifluorescence microscope equipped with a digital camera (ORCA; Hamamatsu, Hamamatsu City, Japan) and the IP Lab software (Scanalytics, Fairfax, VA). Confocal images were acquired using $40 \times$ oil-immersion lens on the Leica TCS SP2 confocal system.

For the analyses of neurite length or contacts of growth cone, 45-60 neurons were randomly selected from triplicate coverslips from two to three independent experiments, and data were collected using the IP Lab software. Data are expressed as means \pm SEM. Two sets of data were compared by Student's $t$ test. Pairs of data sets in experiments with multiple data sets were compared by one-way ANOVA and Tukey's post test.

The intensity of NG2 immunofluorescence in control and adenoNG2-infected cells was measured using BioQuant. Images were captured with IP Lab using a 12-bit camera under nonsaturating exposure conditions. The average intensity was measured in a region of interest defined manually along the contour of the cells. Background levels were determined by similarly drawing a region of interest in a cell-free area of the coverslip. Data were plotted after background subtraction.

Preembedding immunoelectron microscopy. P2 rats were anesthetized and perfused transcardially with $20 \mathrm{ml}$ of fixative containing $4 \%$ paraformaldehyde and $0.2 \%$ glutaraldehyde (Electron Microscopy Science, Fort Washington, PA) in $0.12 \mathrm{~m}$ phosphate buffer, $\mathrm{pH} 7.2$ (PB). The brains were then dissected out and postfixed for $1 \mathrm{~h}$ at $4^{\circ} \mathrm{C}$ in the same fixative. After washing with $\mathrm{PB}, 100 \mu \mathrm{m}$ coronal sections were cut using a vibratome. Sections were first immersed in PBS-NGS for $1.5 \mathrm{~h}$ at room temperature and then incubated at $4^{\circ} \mathrm{C}$ overnight in a rabbit antibody to the extracellular domain of rat NG2 (NG2EC; a gift from Dr. W. Stallcup) diluted 1:2000 in PBS-NGS. The primary antibody was detected by the $\mathrm{ABC} /$ peroxidase method using diaminobenzidine (DAB) as substrate (Vectastain Elite kit; Vector Laboratories). Sections were postfixed with $2 \%$ paraformaldehyde and $1.25 \%$ glutaraldehyde in $0.12 \mathrm{M}$ phosphate buffer for $1 \mathrm{~h}$ at room temperature followed by incubation in $1 \% \mathrm{OsO}_{4}$ in $0.12 \mathrm{M}$ cacodylate buffer, $\mathrm{pH} 7.2$, for $45 \mathrm{~min}$ at room temperature. Sections were then dehydrated through a series of $50,70,86,96$, and $100 \%$ ethanol (Electron Microscopy Science) for $10 \mathrm{~min}$ each and flatembedded in Epon (Electron Microscopy Science) and polymerized at $65^{\circ} \mathrm{C}$ for $2 \mathrm{~d}$.

\section{Results}

\section{Axons do not avoid but form contacts with NG2 cells in vitro}

To determine whether NG2 cells repel growing axons similarly to purified NG2 proteoglycan, we examined the effects of NG2 cells on dissociated hippocampal neurons in culture. Hippocampal neurons from postnatal day 1 (P1) rats were seeded onto a culture of rat NG2 cells and grown for $16 \mathrm{~h}$. The cocultures were double immunolabeled for NG2 and $\beta$ III-tubulin to detect NG2 cells and neurons, respectively. As shown in Figure 1, the tips of the $\beta$ III-tubulin-positive neurites were frequently associated with NG2 cells. The percentage of neurite tips that were associated with NG2 cells $(66 \% ; n=23)$ was significantly higher than that of the total surface area of the coverslips occupied by NG2 cells $(10 \%)$ (Fig. 1 $A, D)$. This suggests that the association of neurite tips with NG2 cells does not simply reflect a random coincidence and that neurite tips prefer to contact NG2 cells compared with the PLL substrate.

To determine whether the observed association of neurite tips with NG2 cells was a result of nonspecific preference of growing neurites for cells in general over PLL, we compared the effects of NG2 cells with those of cells that are known to express neuriteinhibitory/growth cone-collapsing molecules. Specifically, we used mature oligodendrocytes that are known to express neurite growth-inhibitory molecules, including myelin-associated glycoprotein (MAG) and Nogo, and MAG-CHO cells (kindly pro- 
vided to us by Drs. Wilfredo Mellado and Marie Filbin, Hunter College, New York, NY) (Fig. $1 A-C$ ). When hippocampal neurons were cocultured with mature oligodendrocytes (Fig. $1 B$ ) or with MAG$\mathrm{CHO}$ cells (Fig. 1C), the percentages of neurite tips associated with $\mathrm{O} 1+$ oligodendrocytes and MAG-CHO cells were $24 \%(n=16)$ and $26 \%(n=17)$, respectively, and both were significantly lower than the percentage of neurite tips associated with NG2 cells (Fig. 1D, black bars). The percentage of the growth area occupied by NG2 cells, oligodendrocytes, and MAG-CHO cells in the cocultures were comparable at 10,14 , and $13 \%$, respectively (Fig. $1 D$, gray bars).

To more directly compare the extent of contact between neurite tips and NG2 cells with that between neurite tips and mature oligodendrocytes, we prepared a neuronglial coculture in which NG2 cells and mature oligodendrocytes coexisted on the same coverslips. After triple labeling of the cultures for $\beta$ III-tubulin, NG2, and O1, the percentage of neurite tips that were contacting NG2 cells and O1+ oligodendrocytes were determined (Fig. 1E,F). Fifty-five percent of the neurite tips contacted NG2 cells, whereas only $9.7 \%$ of the neurite tips contacted oligodendrocytes. Furthermore, many of the neurites seemed to be turning away from the $\mathrm{O} 1+$ oligodendrocytes and directed toward the NG2 + cells (Fig. 1E). These findings indicate that growth cones of hippocampal neurons do not avoid but actively contact NG2 cells.

Time-lapse microscopy was performed to examine the dynamic response of the growth cones after contacting NG2 cells. A representative behavior is shown in Figure $2 A$. The growth cone of a hippocampal neuron (bottom right, arrow) moved to and from an NG2 cell process (top left, arrowhead) during the first $30 \mathrm{~min}$ and eventually grew toward the NG2 cell (60 $\mathrm{min}$ ) and remained stably connected to the NG2 cell for more than $1 \mathrm{~h}$ until the end of the recording (120 min). Nine of 10 growth cones were attracted toward an NG2 cell and remained in contact with the NG2 cell for at least $30 \mathrm{~min}$. The remaining growth cone was indifferent to the NG2 cell nearby and did not move toward or away from it. This behavior was clearly distinct from the rapid repulsive behavior of the growth cone that contacted a MAG-expressing cell (Fig. 2B). The growth cone (center) that encountered a MAG-CHO cell (bottom) withdrew its filopodia rapidly within $6 \mathrm{~min}$ after the initial contact. The growth cone continued to withdraw and ultimately collapsed into a club-shaped morphology by $75 \mathrm{~min}$. Six of 13 growth cones retracted within $30 \mathrm{~min}$ after contact with a MAG-CHO cell. Seven of 13 growth cones were indifferent to the MAG-CHO cell. Scale bar: $\boldsymbol{E}, 24 \mu \mathrm{m}$.
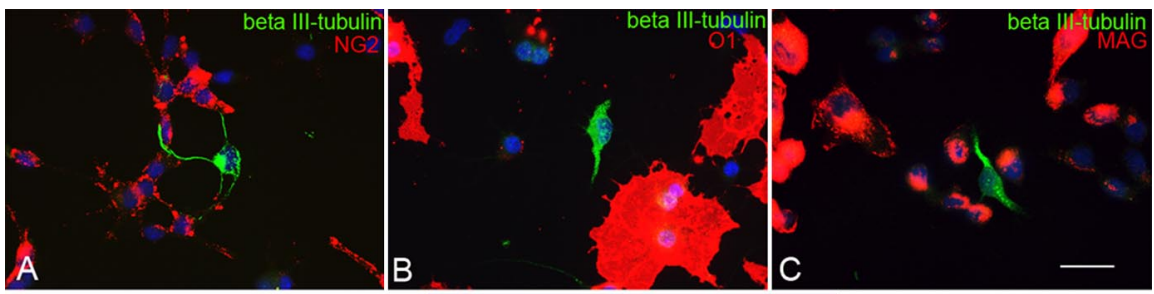

$\%$ Neurite tips contacting cells
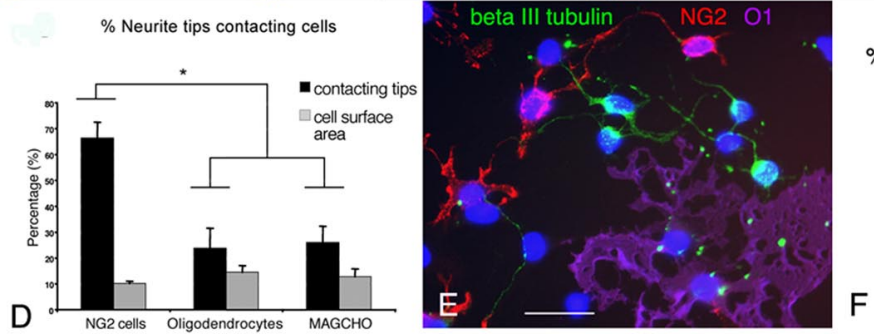

$\%$ Neurite tips contacting

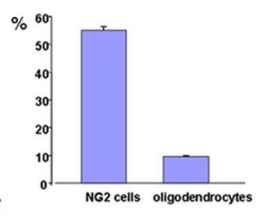

Figure 1. Relationship between hippocampal neurites and NG2 cells in vitro. $\boldsymbol{A}-\boldsymbol{C}, \mathrm{P} 1$ hippocampal neurons grown on NG2 cells $(\boldsymbol{A})$, mature oligodendrocytes $(\boldsymbol{B})$, and MAG-CH0 cells $(\boldsymbol{C})$ for $16 \mathrm{~h}$ and double immunolabeled for $\beta$ III-tubulin (green) and NG2 $(\boldsymbol{A})$, $01(\boldsymbol{B})$, or MAG $(\boldsymbol{C})$ in red. Scale bar: in $\boldsymbol{C}(\boldsymbol{A}-\boldsymbol{C}), 24 \mu \mathrm{m}$. D, Quantification of the contact between neurites and cellular substrate. Black bars, Percentage of neurite tips associated with each type of non-neuronal cellular substrate. Gray bars, Percentage of surface area occupied by each type of non-neuronal cellular substrate. A significantly greater percentage of neurites are associated with NG2 cells compared with mature oligodendrocytes or MAG-CHO cells ( ${ }^{*} p<0.001$, one-way ANOVA with Tukey's post analysis). $\boldsymbol{E}$, $\boldsymbol{F}$, P1 hippocampal neurons grown on a mixed culture of NG2 cells (red) and mature oligodendrocytes labeled for 01 (purple). Neurites labeled for $\beta$ III-tubulin (green) appear to be turning away from the $01+$ cell toward the NG2 + cells. $\boldsymbol{F}$ represents quantification of the contact between neurite tips and NG2 cells or oligodendrocytes. Data in $\boldsymbol{D}$ and $\boldsymbol{F}$ are shown as means \pm SEs.
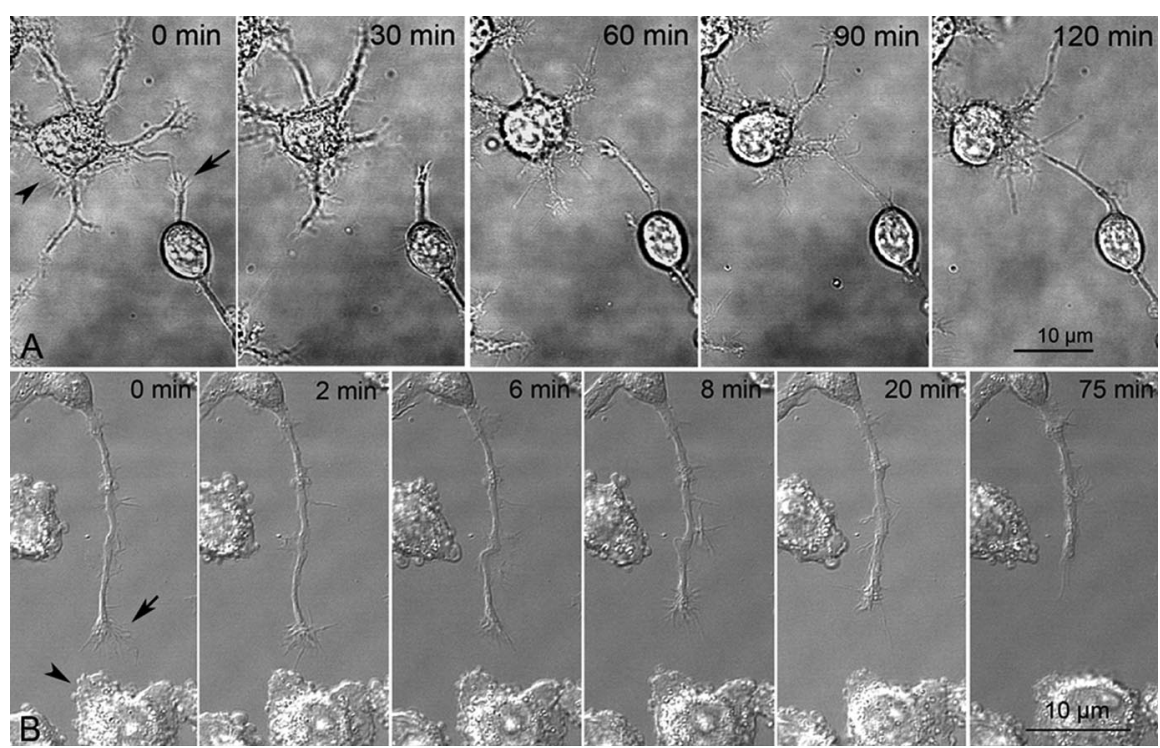

Figure 2. Time lapse images showing the response of a growth cone to an NG2 cell and a MAG-CHO cell. $\boldsymbol{A}$, Top panels, Response of a growth cone (arrow) to an NG2 cell (arrowhead). $\boldsymbol{B}$, Bottom panels, Response of a growth cone (arrow) to a MAG-CHO cell (arrowhead). Scale bar, $10 \mu \mathrm{m}$. The growth cone did not retract or collapse after encountering an NG2 cell but formed a stable association that lasted over $1 \mathrm{~h}$. In contrast, the growth cone that encountered a MAG-CHO cell retracted and ultimately collapsed.

None of the growth cones remained attached to a MAG-CHO cell for $>30 \mathrm{~min}$. These observations demonstrate that NG2 cells elicit a response in neurites that is distinct from the response to MAG-CHO cells or mature oligodendrocytes that are known to repel axons.

Axonal growth cones form extensive contacts with NG2 cells in the developing corpus callosum in vivo

We next examined whether growth cones formed similar extensive contacts with NG2 cells in the developing corpus callosum. 

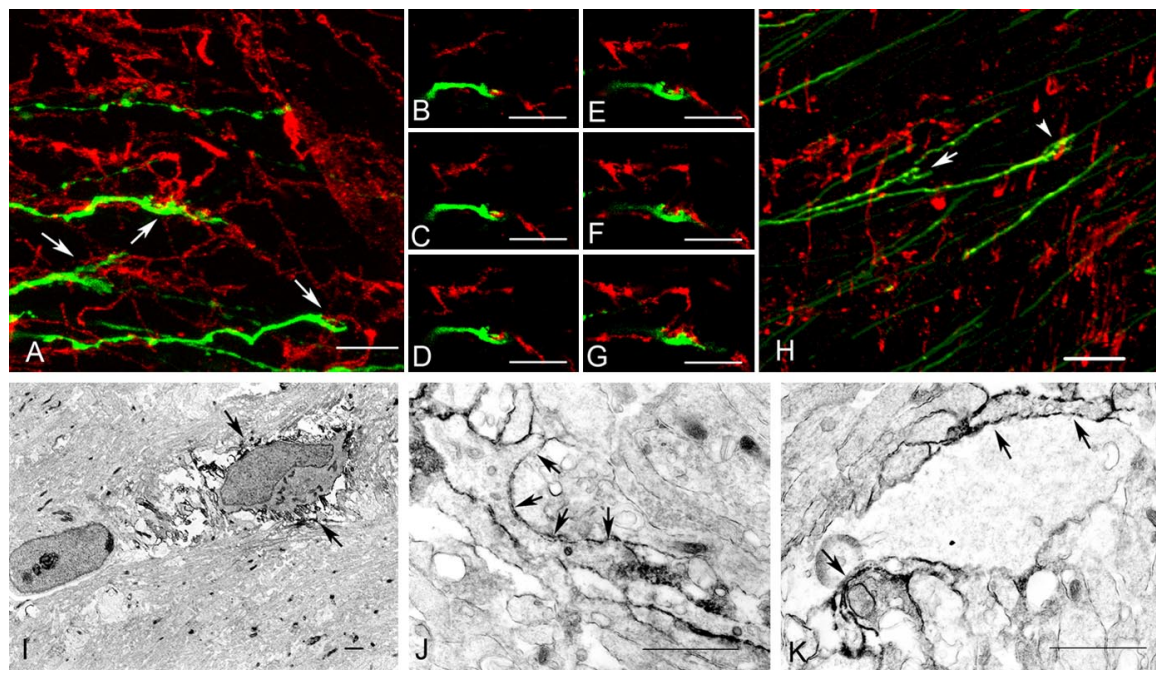

Figure 3. Spatial relationship between axonal growth cones and NG2 cells in P2 corpus callosum. $\boldsymbol{A}-\boldsymbol{H}$, Confocal laser-scanning micrographs of $100 \mu \mathrm{m}$ sections through the corpus callosum of a P2 rat that had been electroporated with pCA-gapgfpm4 atE17 and immunolabeled for GFP (green) and NG2 (red; $\boldsymbol{A}-\boldsymbol{G}$ ) or GLAST (red; $\boldsymbol{H}$ ). Growth cones of GFP-labeled neurons are traversing the corpus callosum from left to right. $A, A$ stack of $25 z$-sections, $0.3 \mu \mathrm{m}$ each. Three growth cones are identified in the field (arrows), all of which are contacted by NG2 cells through multiple filopodia. $\boldsymbol{B}-\mathbf{G}$, Six consecutive $z$-sections of the growth cone in the center of the image in $\boldsymbol{A}$ showing interdigitating contact between the growth cone and the NG2 cell process. $\boldsymbol{H}, A$ stack of 41 $z$-sections, $0.16 \mu \mathrm{m}$ each, through a section double labeled for GFP and GLAST. Most of the GLAST + astrocytic processes are perpendicular to the long axis of the growth cone and had little (arrowhead) or no (arrow) contact with the growth cone. I-K, Preembedding immunolabeling for NG2 in P2 corpus callosum using an antibody to the extracellular domain of rat NG2. I, A lowmagnification image showing a multiprocessed NG2 cell (arrows). $\boldsymbol{J}, \boldsymbol{K}$, Growth cones, identified as irregularly shaped endings of the axon containing various sized vesicles, are contacted by NG2-positive processes on both sides (arrows). Scale bars: $\boldsymbol{A}-\boldsymbol{H}, 20$ $\mu \mathrm{m} ; \boldsymbol{I}-K, 1 \mu \mathrm{m}$.

Callosal axons were labeled by in utero electroporation of a plasmid encoding membrane-anchored green fluorescence protein (pCA-gapgfpm4) (Okada et al., 1999) into E17 rat embryos. Examination of electroporated rats at $\mathrm{P} 2$ revealed unilateral clusters of GFP-labeled neuronal cell bodies mostly in neocortical layers II and III (data not shown) and bundles of axons through the corpus callosum. The spatial relationship between growth cones and NG2 cells was analyzed by confocal microscopy of $100 \mu \mathrm{m}$ coronal brain sections immunolabeled for NG2 and GFP. Only growth cones with their entirety within the $100 \mu \mathrm{m}$ slice were analyzed. Growth cones were identified as irregularly shaped endings of GFP-positive axons. In the stacked confocal image shown in Figure $3 A$, three growth cones with complex morphology were identified (arrows), all of which appeared to be contacting NG2 cells through multiple filopodia. A series of six consecutive individual $z$-sections through one of the growth cones revealed the interdigitating nature of the contact between an NG2 cell and the growth cone (Fig. 3B-G). Among 19 growth cones that were randomly sampled in the corpus callosum of three P2 rats, 16 growth cones $(84.2 \%)$ were contacting NG2 cells, and the majority of them contacted NG2 cells through multiple filopodia.

The spatial relationship between growth cones and NG2 cells was compared with that between growth cones and astrocytes in the $\mathrm{P} 2$ corpus callosum. Astrocytes were identified by immunolabeling for the glial glutamate transporter, GLAST, which is expressed at the cell surface. There was little contact between the growth cone and GLAST-expressing astrocytes. Unlike NG2 cell processes, which were parallel to and extensively intertwined with the axonal filopodia, GLAST + astrocytic processes ran perpendicular to the growing axons and made little or no contact with the growth cones (Fig. $3 H$ ).
To further verify that there was direct contact between growth cones of callosal axons and NG2 cells, preembedding NG2 immunoelectron microscopy was performed on slices from $\mathrm{P} 2$ rat corpus callosum using a rabbit antibody against the extracellular domain of rat NG2. Electron dense peroxidase products of DAB were detected on the surface of an NG2 cell with multiple processes found among parallel rows of callosal axons (Fig. 3I, arrows). We could identify many growth cones that displayed the ultrastructural characteristics previously described (Povlishock, 1976; Gorgels, 1991a), consisting of an irregularly shaped widening of $0.5-2 \mu \mathrm{m}$ in diameter that contained mitochondria and various sized vesicles and extended into an organelle-poor distal region. Both the organelle-rich proximal region and the organelle-poor distal region of growth cones were apposed to NG2immunolabeled membranes (Fig. 3J,K). In some cases, both growth cones and axonal shafts were surrounded by NG2immunopositive membranes. These findings indicate that the association between growth cones and NG2 cells observed by confocal microscopy represents direct membrane contact between the growth cone and NG2 cell processes. We did not observe clusters of synaptic vesicles or significant postsynaptic density-like structures at growth cone-NG2 cell junctions.

\section{NG2 cells promote axonal outgrowth}

We next examined the effect of NG2 cells on axonal outgrowth in a neuron-glial coculture system. We obtained a highly enriched population of NG2 cells and astrocytes that were $>90-95 \%$ pure (Fig. 4A,B) (see also Yang et al., 2005). P1 rat hippocampal neurons were seeded onto a high-density culture of purified NG2 cells or astrocytes. For control, neurons were plated on NIH 3T3 fibroblasts or directly onto PLL-coated coverslips without a cellular substrate. After $16-18 \mathrm{~h}$ in culture, hippocampal neurons on various substrates extended one to several neurites, which could be easily measured within one or two microscopic fields. Cocultures were fixed $16 \mathrm{~h}$ after neurons were added and immunostained for phosphorylated neurofilaments to reveal axons. Neurons cocultured with NG2 cells or astrocytes extended longer axons than those cultured on NIH 3T3 fibroblasts or on PLL alone (Fig. 4C-F). Quantification of total axonal length revealed that neurons cocultured with NG2 cells or astrocytes extended axons that were twice as long as those on NIH 3T3 cells or on PLL (Fig. 4G). Quantification of the length of the longest axon also revealed a twofold greater length of axons from neurons grown on NG2 cells and astrocytes compared with those grown on NIH 3T3 cells or on PLL (Fig. $4 H$ ). We noted that axons that extended on NG2 cells were thinner than those on astrocytes (Fig. 4C,D). It appeared that a slightly higher percentage of neurons cocultured with NG2 cells contained multiple axons compared with neurons cocultured with astrocytes, but the difference was not statistically significant.

Because astrocytes have been shown to promote neurite out- 
growth (Noble et al., 1984; Fallon, 1985; Smith et al., 1986; Neugebauer et al., 1988), control experiments were performed to rule out the possibility that the neurite growth-promoting effect of NG2 cells was derived from a small percentage of astrocytes present in our NG2 cell cultures and not directly an effect of NG2 cells. Based on the purity of NG2 cell cultures $(>93 \%)$ and the total number of NG2 cells on the coverslips, the maximum number of astrocytes in our OPC cultures was estimated to be 613 . Next, the growthpromoting effect of 613 astrocytes was theoretically determined by fitting this number on a dose-response curve generated by measuring the growthpromoting effects of 100-10,000 astrocytes. The calculated value of axonal length in the presence of 613 astrocytes was significantly lower than the length of axons from neurons cocultured with NG2 cells, suggesting that the growthpromoting effect of NG2 cells was not mediated by contaminating astrocytes. These results demonstrate that, unlike purified NG2 proteoglycan, NG2 cells promote axonal growth from hippocampal neurons.

To determine whether the axonal growth-promoting effects of NG2 cells were mediated by soluble factors, we prepared inverted cocultures in which coverslips containing glia were placed inverted onto a porous tissue culture insert, which then were placed over separate coverslips containing neurons. Both glia and neurons were immersed in the same media to allow free diffusion of soluble molecules. After $16 \mathrm{~h}$ of incubation, the neurons were fixed, immunolabeled for phosphorylated neurofilaments, and axonal lengths were measured as above. Standard cocultures were prepared in parallel as positive control. The total axonal lengths (Fig. 4I) or the length of longest axons (data not shown) of neurons cocultured with inverted coverslips containing NG2 cells were not significantly different from those of neurons grown on PLL or NIH 3 T3 cells. This suggests that the axonal growth-promoting effect of NG2 cells was mediated either by direct contact or by a slowly diffusible extracellular signal.

\section{Altered levels of NG2 do not affect the growth-promoting effect of NG2 cells}

The observations described above revealed that NG2 cells do not repel but form extensive contacts with axonal growth cones and promote axonal growth. These effects of NG2 cells on growing axons differ from the reported inhibitory effects imparted by the NG2 proteoglycan (Dou and Levine, 1994; Chen et al., 2002b). The difference may be attributable to the difference in the amount of the NG2 molecule presented to the growing axons. The concentration of NG2 that is detected by axons growing on a surface coated with purified NG2 or membrane preparations from NG2-expressing cells may be significantly higher than the physiological concentration of NG2 detected by axons contacting intact NG2 cells. Therefore, we performed the following experiments to examine the response of axons to NG2 cells expressing different levels of NG2.

\section{Effects of elevated NG2}

To determine whether elevated levels of NG2 presented on NG2 cells could render NG2 cells inhibitory to axonal growth, we transduced rat NG2 cells in culture with an adenoviral vector encoding full-length rat NG2 cDNA, adeno-NG2. Two days after infection, the level of NG2 on infected and uninfected cells was determined by immunocytochemistry and Western blotting. Quantitative live-cell immunocytochemistry revealed that, at a moi of 2 (data not shown) or 5, adeno-NG2 increased cell surface NG2 expression by fivefold (Fig. 5A-C). Western blotting showed that virally expressed NG2 was predominantly in the form of high-molecular-weight chondroitin sulfate proteoglycan (Fig. 5D, lane 3), which could be converted into $275-300 \mathrm{kDa}$ core proteins by chondroitinase $\mathrm{ABC}$ treatment (Fig. 5D, lane 4), identical in size to the endogenous core protein (lane 2). Quantification of the density of the NG2 core protein bands normalized to that of GAPDH bands revealed a 50-fold increase in the level of NG2 expression in adeno-NG2-infected cells compared 

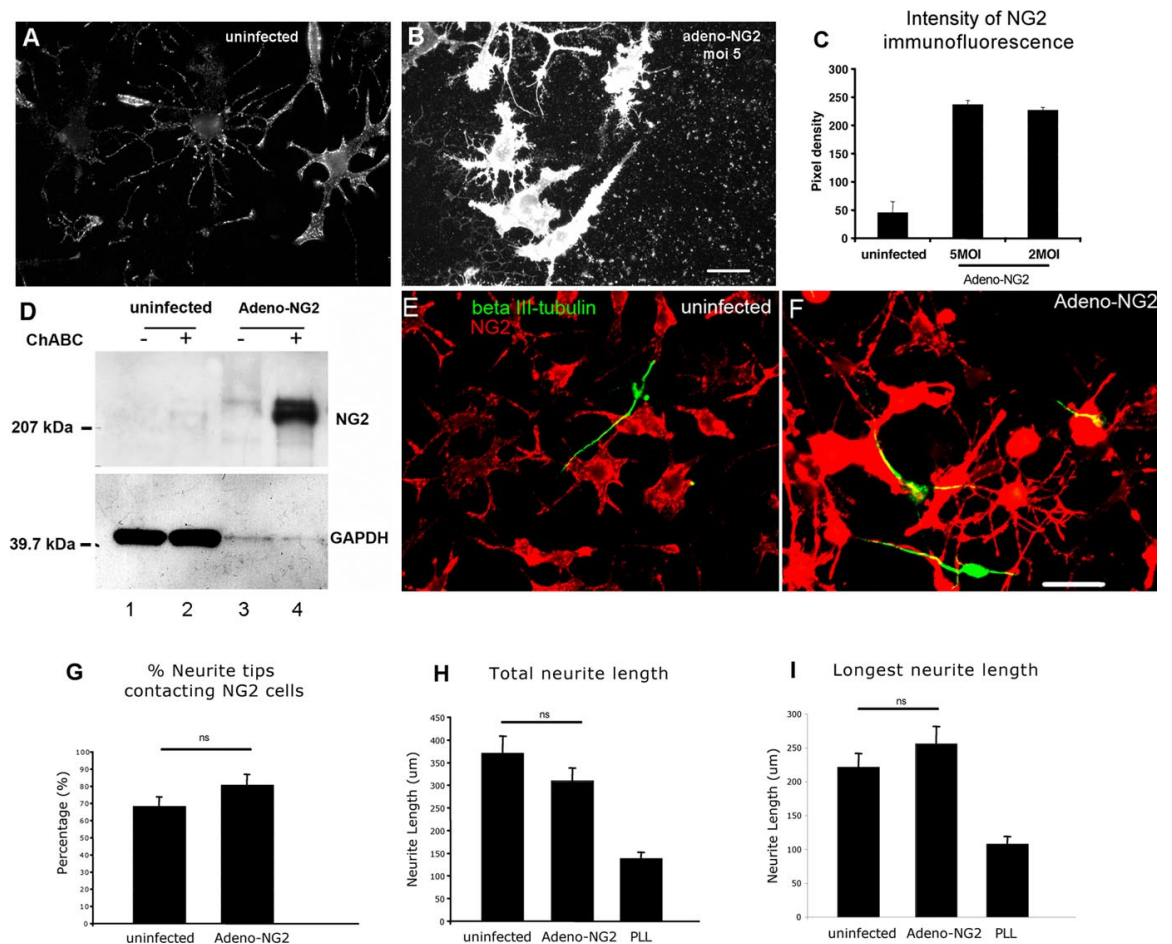

Figure 5. Effects of increased NG2 expression on neurite growth. $A-D$, Comparison of the level of NG2 expression in control NG2 cells and in NG2 cells infected with adeno-NG2. $\boldsymbol{A}, \boldsymbol{B}$, Surface immunofluorescence labeling (live-cell labeling) for NG2 on uninfected $(\boldsymbol{A})$ and adeno-NG2-infected cells ( $\boldsymbol{B}$; moi 5). Images were acquired under identical exposure conditions below pixel saturation. Scale bar: (in $\boldsymbol{B}) \boldsymbol{A}, \boldsymbol{B}, 12 \mu \mathrm{m}$. C, Quantification of fluorescence intensity of uninfected NG2 cells and NG2 cells infected with adeno-NG2. Cells transduced with adeno-NG2 expressed fivefold more surface NG2 than uninfected NG2 cells. D, Western blots comparing the amount of NG2 in extracts of uninfected and adeno-NG2-infected NG2 cells. The same blot was probed with antibodies to NG2 (top) and GAPDH (bottom) ChABC+: extracts treated with chondroitinase ABC. Smaller amounts of protein extracts from adeno-NG2-infected cells were loaded to allow for densitometric analyses of the samples within the dynamic ranges of the pixels, as seen by the weaker GAPDH bands in lanes 3 and 4 . The positions of molecular weight standards are indicated on the left. $\boldsymbol{E}-\boldsymbol{I}$, Response of P1 hippocampal neurons to NG2 cells expressing elevated levels of NG2. $\boldsymbol{E}, \boldsymbol{F}$, Double-immunofluorescence labeling for NG2 (red) and $\beta$ III tubulin (green) to illustrate the spatial relationship between neurites and NG2 cells expressing normal $(\boldsymbol{E})$ or increased levels of surface NG2 after adeno-NG2 transduction ( $\boldsymbol{F}$; moi 5). Scale bar: (in $\boldsymbol{F}) \boldsymbol{E}, \boldsymbol{F}, 24 \mu \mathrm{m}$. $\boldsymbol{G}$, Percentage of neurite tips contacting uninfected or adeno-NG2-infected NG2 cells. ns, No statistically significant difference between the number of neurite tips contacting uninfected and adeno-NG2-infected NG2 cells ( $p=0.239, t$ test). $\boldsymbol{H}$, Total neurite lengths of neurons grown on uninfected or adeno-NG2-infected NG2 cells. ns, No significant difference ( $p>0.05$, one-way ANOVA). They were significantly longer than neurite lengths on PLL ( $p<0.001$, one-way ANOVA). $I$, The lengths of the longest neurite of neurons grown on uninfected or adeno-NG2-iinfected NG2 cells. ns, No significant difference ( $p>0.05$, one-way ANOVA). They were significantly longer than neurite lengths on PLL ( $p<0.001$, one-way ANOVA). Error bars indicate SE.

with uninfected cells. The greater increase in the level of NG2 expression detected by Western blotting may have been caused by greater accumulation of intracellular pools of NG2 in adenoNG2-transduced cells. Transduction of NG2 cells with adenoNG2 did not affect the survival of infected NG2 cells at 2 or 5 moi.

To determine whether NG2 cells expressing elevated levels of NG2 could induce a repulsive response in axons, P1 rat hippocampal neurons were cocultured with NG2 cells expressing physiological or elevated levels of NG2 for $16 \mathrm{~h}$ and processed for immunocytochemistry. The spatial relationship between hippocampal neurites and NG2 cells expressing physiological or elevated levels of NG2 is shown in Figure 5, $E$ and F. Neurites seemed to end equally frequently on both types of NG2 cells. Quantification revealed no difference in the percentage of neurite tips that contacted NG2 cells expressing normal or elevated levels of NG2 (Fig. $5 G$ ). On initial examination of the coverslips, it seemed that neurites contacted adeno-NG2-infected cells at a steeper angle, rather than growing along the cell surface as they appeared to do on uninfected cells. To evaluate this further, we quantified the proportion of the neurite shafts that were contact- ing NG2 cells. Contrary to our prediction, $\sim 30 \%$ of the entire lengths of neurites were associated with NG2 cells regardless of the level of NG2, suggesting that neither the tips nor the shafts of growing hippocampal axons avoided NG2 cells expressing at least fivefold elevated levels of NG2.

To determine whether elevated NG2 levels affected the ability of NG2 cells to promote axonal growth, neurite growth assays were performed using P1 hippocampal neurons cocultured with uninfected or adeno-NG2-infected NG2 cells. Quantification of total neurite length per neuron (Fig. 5H) and longest neurite length (Fig. 5I) revealed no statistically significant difference between neurons cocultured with NG2 cells expressing normal and elevated levels of NG2. In both cases, neurons cocultured with NG2 cells extended neurites that were twice as long as those grown on PLL. Thus, at least a fivefold increase in the level of NG2 expressed by NG2 cells failed to cause growth cone collapse or inhibit neurite growth, suggesting that the NG2 proteoglycan is not inhibitory to growing axons when presented on NG2 cells.

\section{Effects of reduced NG2}

We next used RNA interference to examine the effects of reduced NG2 expression on axonal growth. Two hairpin siRNAs, both directed at the $3^{\prime}$-untranslated region of the rat NG2 mRNA (NG2_7217hp and NG2_7292hp), were generated using an expression vector driven by mouse U6 promoter (Yu et al., 2002). The plasmids were transfected into NG2 cells by nucleofection, which resulted in $40-60 \%$ transfection efficiency. When purified NG2 cells were cotransfected with the NG2_7217hp siRNA and a plasmid encoding GFP and analyzed 4 d later, $90 \pm 19 \%$ ( 15 fields; $n=92$ ) of GFP-positive cells had little or no detectable NG2 (Fig. 6A, arrows). The oligodendrocyte progenitor phenotype of the siRNA-treated cells was confirmed by the presence of the $\alpha$-receptor of platelet-derived growth factor (PDGFR $\alpha$ ) (Nishiyama et al., 1996b) on cells that were not expressing NG2 (Fig. 6B). Similarly, the NG2_7292hp construct was also effective in silencing NG2 expression on NG2 cells (data not shown). Neither construct affected NG2 cell survival, and both constructs were used in the following experiments.

To examine the effect of reduced NG2 expression on axons, P1 hippocampal neurons were cultured on control untransfected NG2 cells or NG2 cells transfected with NG2_7217hp or NG2_7292hp and doubled immunolabeled for $\beta$ III-tubulin and NG2 after $16 \mathrm{~h}$. The percentage of neurite tips that were contacting NG2 cells was not significantly different between untransfected NG2 cells $(72 \pm 33 \%)$ and siRNA-transfected cells ( $66 \pm 31 \%$ for NG2_7217hp; $62 \pm 39 \%$ for NG2_7292hp) (Fig. $6 C)$. To further evaluate the effects of reduced NG2 expression on 

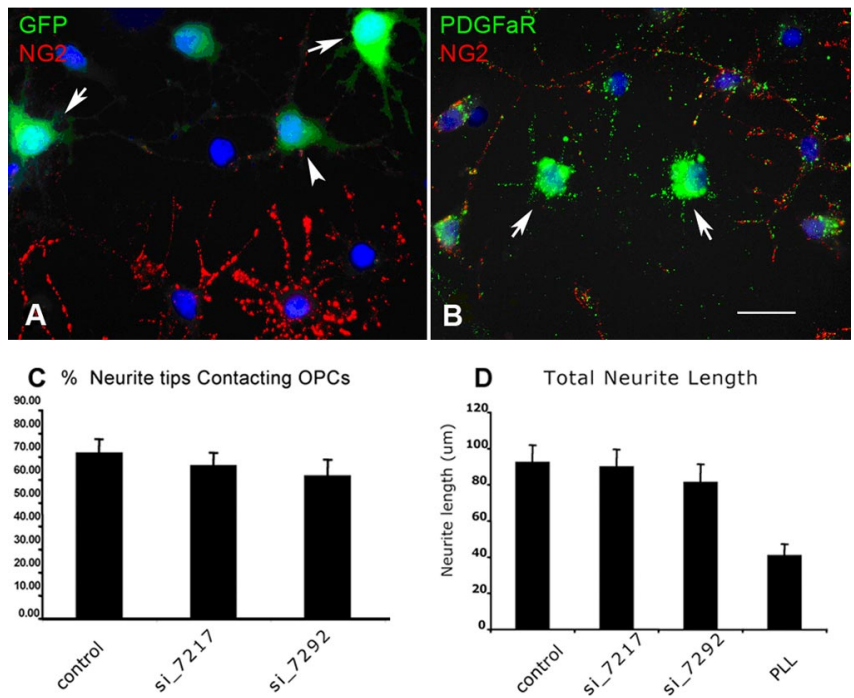

Figure 6. Effects of reduced NG2 expression on neurite growth. $A$, Purified proliferating NG2 cells were cotransfected with plasmids containing NG2_7217hp and pCA-gapgfpm4 and immunolabeled for NG2 (red) $4 \mathrm{~d}$ later. GFP + cells (green) have little (arrowhead) or no detectable NG2 (arrows), whereas GFP-negative untransfected cells expressed NG2. B, Purified proliferating NG2 cells transfected with NG2_7217hp plasmid and double labeled for NG2 (red) and PDGFR $\alpha$ (green) $4 \mathrm{~d}$ later. Cells that have little or no NG2 express PDGFR $\alpha$ (arrows). Scale bar: (in $B) A, B, 24 \mu \mathrm{m}$. $C, D$, Quantification of neurites from $\mathrm{P} 1 \mathrm{hippocampal}$ neurons grown for $16 \mathrm{~h}$ on PLL, untransfected NG2 cells and on NG2 cells transfected with NG2_7217hp (si_7217) or NG2_7292hp (si_7292) and double labeled for NG2 and $\beta$ III-tubulin. $\boldsymbol{C}$, Percentage of $\beta$ IIItubulin + hippocampal neurite tips contacting untransfected NG2 cells (control) or NG2 cells transfected with either NG2_7217hp siRNA (si_7217) or NG2_7292hp siRNA (si_7292). There was no statistically significant difference between the percentage of neurite tips contacting control NG2 cells and those contacting siRNA-transfected NG2 cells ( $p=0.29$, Student's t test). $D$, Lengths of $\beta$ III-tubulin + hippocampal neurites per neuron grown on uninfected NG2 cells (control) or on siRNA-transfected NG2 cells or directly on PLL. There was no statistical difference between the lengths of neurites from neurons grown on control NG2 cells and those on siRNAtransfected NG2 cells. Neurites on transfected and untransfected NG2 cells were both longer than neurites grown on PLL ( $p<0.01$, one-way ANOVA with Tukey's post test). For neurons seeded on siRNA-transfected NG2 cells, only neurons grown on NG2 cells expressing reduced levels of NG2 were included for analysis. Error bars indicate SE.

the ability of growth cones to contact NG2 cells, we determined the percentage of neurite tips that were contacting cells with strong NG2 expression and those contacting cells with weak or no NG2 expression on the same coverslips. On coverslips containing cells transfected with NG2_7217hp siRNA construct, $41.2 \pm$ $4.6 \%$ of the neurite tips contacted cells with strong NG2 expression and $44.9 \pm 8.7 \%$ of neurite tips contacted cells with reduced NG2 expression. On coverslips transfected with NG2_7292hp siRNA construct, $49.2 \pm 4.6 \%$ of neurite tips contacted strongly $\mathrm{NG} 2+$ cells and $45.6 \pm 6.5 \%$ of the neurite tips contacted weakly NG2 + cells. Thus, there appeared to be no significant difference in the frequency with which the growth cones contacted control cells and cells with reduced NG2.

When neurite lengths were measured, there was no significant difference in the length of neurites between neurons grown on untransfected NG2 cells and those grown on siRNA-transfected cells (Fig. 6D). These data suggest that regardless of the level of NG2 at the surface, NG2 cells elicit an adhesive/attractive response rather than a repulsive response in hippocampal neurons.

\section{NG2 cells express fibronectin and laminin at the cell surface} We examined whether NG2 cells express extracellular or cell surface molecules that might contribute to the observed neurite growth-promoting effect. Immunolabeling cultured NG2 cells
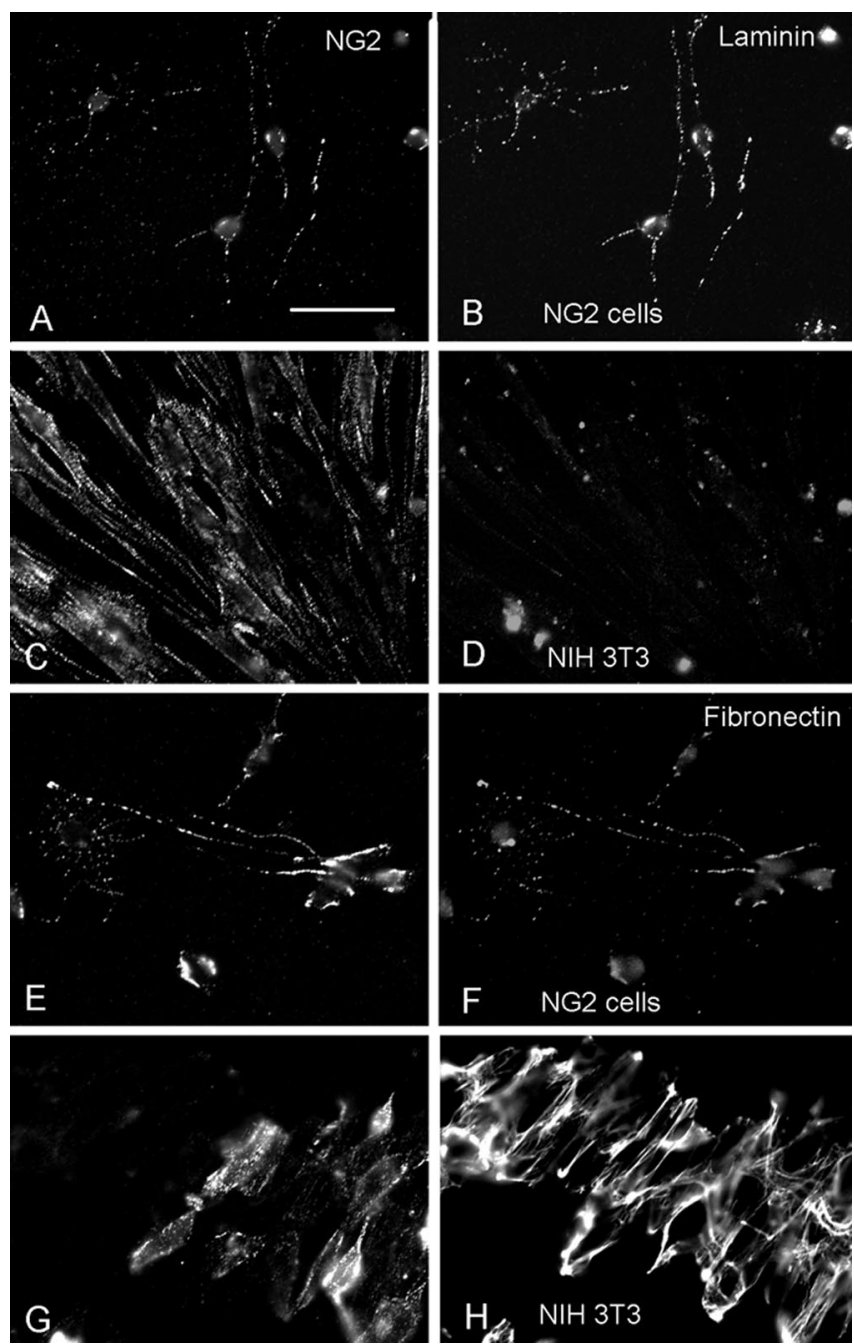

Figure 7. Cell surface expression of laminin and fibronectin on NG2 cells. Doubleimmunofluorescence labeling for NG2 ( $\boldsymbol{A}, \boldsymbol{C}, \boldsymbol{E}, \boldsymbol{G}$; detected with Alexa 594 goat anti-rabbit immunoglobulins) and laminin $(\boldsymbol{B}, \boldsymbol{D})$ or fibronectin $(\boldsymbol{F}, \boldsymbol{H})$, detected with Alexa 488 goat antimouse immunoglobulins, on secondary cultures of NG2 cells from $P 3$ rat cortex $(A, B, E, F)$ and mouse NIH 3T3 cell fibroblasts $(\boldsymbol{C}, \boldsymbol{D}, \boldsymbol{G}, \boldsymbol{H})$. Scale bar: (in $\boldsymbol{A}) \boldsymbol{A}-\boldsymbol{H}, 24.4 \mu \mathrm{m}$. Both laminin and fibronectin are colocalized with NG2-immunoreactive puncta on rat NG2 cells. Little laminin is detected on NIH 3 T3 cells. Fibronectin on NIH $3 \mathrm{~T} 3$ appears extracellular.

from P3 rat brain revealed a small amount of punctuate cell surface staining for both laminin and fibronectin (Fig. $7 B, F$, respectively). This was distinct from the typical wavy extracellular pattern of fibronectin staining observed on NIH $3 \mathrm{~T} 3$ fibroblasts with the same antibody (Fig. 7H). Double labeling for NG2 and laminin or fibronectin revealed extensive colocalization between NG2 and laminin or fibronectin on NG2 glial cells. This was not attributable to cross-reactivity between the primary or secondary antibodies, because fibronectin was not detected on NG2-positive puncta on NIH 3T3 cells (Fig. 7G,H), and little laminin was detected on these cells despite the presence of NG2 (Fig. 7C,D). Furthermore, control experiments in which rat NG2 cells were singly labeled with anti-NG2 antibody followed by incubation with Alexa 594-conjugated anti-rabbit antibody to detect NG2 and Alexa 488-conjugated anti-mouse antibody that had been used to detect laminin or fibronectin did not result in any detectable fluorescence in the 488 channel (data not shown). These observations indicate that NG2 cells express a small amount of fibronectin and laminin that is closely associated with NG2 at the cell surface. 


\section{Discussion}

\section{NG2 cells support growth cone adhesion and neurite extension}

In the rodent brain, NG2 cells make their appearance in late embryonic stages and become uniformly distributed throughout the cortex and white matter by the end of the first postnatal week (Nishiyama et al., 1996a, 2002). White matter tracts of the corpus callosum and hippocamposeptal fibers contain axons that originate in the neocortex and hippocampus, respectively, and are populated by NG2 cells during the time when these axons navigate through the tracts (Alonso and Kohler, 1982; Ozaki and Wahlsten, 1992; Koester and O'Leary, 1994). The NG2 proteoglycan on the surface of NG2 cells carries a small number of chondroitin sulfate chains (Stallcup, 2002) and has also been shown to cause growth cone collapse and inhibit axonal growth (for review, see Chen et al., 2002b), a characteristic shared by many chondroitin sulfate proteoglycans (Smith et al., 1986, 1990; Hoke and Silver, 1996; Moon et al., 2001; Bradbury et al., 2002; Silver and Miller, 2004). However, little is known about the effects of intact NG2 cells on growing axons.

In the present study, we have examined the effects of NG2 cells, rather than the NG2 molecule, on growing axons. Using rat NG2 cell-neuronal cocultures, we have demonstrated that axons of neonatal hippocampal neurons are not repelled by NG2 cells but adhere to them and extend longer neurites when cocultured with NG2 cells than when grown directly on PLL or on NIH 3T3 fibroblasts. Thus, contrary to the previous reports demonstrating neurite growth-inhibitory effects of the NG2 proteoglycan (Chen et al., 2002b), our observations indicate that NG2 cells allow axons to contact them without causing growth cone collapse and retraction and promote neurite extension.

\section{Increased NG2 expression did not alter neurite adhesion or extension on NG2 cells}

One possible explanation for the lack of neurite growthinhibitory effect of NG2 cells in our study is that the level of the NG2 proteoglycan at the surface of NG2 cells was significantly lower than the amount of NG2 presented to axons in the culture substratum or as a membrane preparation in other studies (Dou and Levine, 1994; Chen et al., 2002a). Because NG2 expression is dramatically upregulated in response to axonal damage (Levine, 1994; Bu et al., 2001; Jones et al., 2002; Tang et al., 2003), it has been widely speculated, although not directly shown, that increased NG2 at sites of injury is responsible for the inability of damaged axons to regenerate through an NG2-rich scar tissue (Fidler et al., 1999; Levine et al., 2001).

Contrary to our prediction, however, we found that altering the level of NG2 on NG2 cells by adenovirus-mediated overexpression of NG2 or by siRNA-mediated NG2 knock-down had no effect on the way in which neuronal growth cones contacted NG2 cells or the ability of neurons to extend neurites on NG2 cells. Despite a significant increase in the amount of NG2 expressed, NG2 cells were not inhibitory to growing axons.

Mature oligodendrocytes, which arise from differentiation of NG2 cells, contain three axonal growth-inhibitory molecules, MAG (McKerracher et al., 1994; Mukhopadhyay et al., 1994), Nogo-A (Chen et al., 2000; GrandPre et al., 2000), and oligodendrocyte-myelin glycoprotein (Kottis et al., 2002; Wang et al., 2002), all of which bind to the same Nogo-66 receptor (Fournier et al., 2001; Liu et al., 2002). In our study, hippocampal axons seldom contacted mature oligodendrocytes or MAGexpressing $\mathrm{CHO}$ cells (Fig. 1), and they quickly withdrew when they encountered MAG-expressing CHO cells (Fig. 2). Such be- havior of the axonal growth cone was clearly distinct from the behavior of axons that encountered NG2 cells. Thus, despite the demonstrated ability of the hippocampal neurons to respond to growth-inhibitory signals from MAG and mature oligodendrocytes in our culture system, the same neurons did not display a repulsive response to NG2 cells, suggesting that an entirely different molecular signaling mechanism exists between NG2 cells and growing axons.

It is possible that the epitope on NG2 that causes growth cones to collapse (Ughrin et al., 2003) is masked on the surface of NG2 cells and is not recognized by neurons unless it becomes exposed by some mechanism such as the action of a protease. The neurite growth-inhibitory effect of NG2 may be sensitive to subtle conformational changes, and may exhibit inhibitory properties only under certain conditions. This may account for the variable results obtained with purified NG2 among different investigators. Trotter and colleagues (Niehaus et al., 1999; Schneider et al., 2001) observed that mouse NG2 is not inhibitory to growing axons. It is also possible that NG2 cells express potent growthpromoting molecules that override the negative effects of NG2 (see below). The combination of specific cell surface molecules that can modify the conformation of NG2 (Asher et al., 2005) and growth-stimulatory molecules expressed by NG2 cells may make these cells different from other NG2-expressing cell types that inhibit neurite growth (Chen et al., 2002a; Shearer et al., 2003).

\section{NG2 cells in vivo are intimately associated with growing axons}

In contrast to mature oligodendrocytes, which inhibit growing axons, astrocytes have been known to support neuronal growth (Denis-Donini et al., 1984; Noble et al., 1984; Fallon, 1985; Smith et al., 1986; Neugebauer et al., 1988). We also observed that neurons grown on astrocytes extend longer neurites than those grown on PLL or NIH 3T3 cells, and the magnitude of neurite growth-promoting effect of NG2 cells was similar to that of astrocytes (Fig. 4). However, the mechanisms underlying the neurite growth-promoting effect of astrocytes may differ from those of NG2 cells, based on the following observations. First, neurites from neurons grown on NG2 cells were thinner and more branched than those that extended on astrocytes. Second, the geometry of axonal growth cones and NG2 cells in the developing corpus callosum was different from that of growth cones and astrocytes identified by GLAST immunoreactivity (Fig. 3). NG2 cell processes ran parallel to and were intricately intertwined with growth cone filopodia. In contrast, GLAST + astrocytic processes displayed minimum contact with growth cone filopodia and were oriented perpendicular to the filopodia. The small spatial gap observed between GLAST + processes and growth cone filopodia may reflect the presence of a repulsive interaction between GLAST + astrocytic processes and growing axons (Shu and Richards, 2001; Shu et al., 2003). Thus, GLAST+ astrocytes and NG2 cells may use different mechanisms to promote axonal elongation. There may be GLAST-negative astrocytes whose processes are oriented radially along the trajectory of growing callosal axons, as previously described (Silver et al., 1982, 1993), and such astrocytes may interact more closely with the growing axons.

Our light and electron microscopic observations on the developing corpus callosum indicate a direct intercellular adhesive contact between NG2 cells and growing axons. This is consistent with the previous observation by Gorgels (1991b) that transient synapse-like contacts exist between axonal growth cones and "immature glial cells" in the developing pyramidal tract in the spinal cord. These observations strongly suggest that NG2 cells in 
the developing corpus callosum are not inhibitory to growing axons. Additional experiments are needed to elucidate the role of NG2 cells in the development of callosal axons in vivo.

Growth cones of retinal ganglion axons have been shown to alternate between phases of pausing and rapid extension as they migrate through the optic nerve to their target (Mason and Wang, 1997). The expression of cell adhesion molecules laminin and fibronectin at the surface of NG2 cells may allow growing axons to "pause" on NG2 cells, as seen in our time-lapse study (Fig. 2). Both fibronectin and laminin have been implicated in axonal growth in situ (Grimpe et al., 2002; Tom et al., 2004). NG2 cells may provide a source for some of these adhesion molecules. Growing axons pausing in their trajectory may be exchanging signaling with NG2 cells through their cell surface receptors. For example, neurotrophins from NG2 cells could focally activate receptors on neurons, and reciprocally, neurotransmitters released from growth cones could activate receptors on NG2 cells. Changes in the expression of such growth-permissive molecules during injury response may alter the NG2 cells to create a more growth-inhibitory cellular substrate for regenerating axons. Additional elucidation of the molecular mechanisms of the interactions between NG2 cells and growing axons may lead to novel ways of exploiting endogenous NG2 cells to promote axonal regeneration after injury.

\section{References}

Alonso A, Kohler C (1982) Evidence for separate projections of hippocampal pyramidal and non-pyramidal neurons to different parts of the septum in the rat brain. Neurosci Lett 31:209-214.

Asher RA, Morgenstern DA, Properzi F, Nishiyama A, Levine JM, Fawcett JW (2005) Two separate metalloproteinase activities are responsible for the shedding and processing of the NG2 proteoglycan in vitro. Mol Cell Neurosci 29:82-96.

Bai J, Ramos RL, Ackman JB, Thomas AM, Lee RV, LoTurco JJ (2003) RNAi reveals doublecortin is required for radial migration in rat neocortex. Nat Neurosci 6:1277-1283.

Bergles DE, Roberts JD, Somogyi P, Jahr CE (2000) Glutamatergic synapses on oligodendrocyte precursor cells in the hippocampus. Nature 405:187-191.

Bradbury EJ, Moon LD, Popat RJ, King VR, Bennett GS, Patel PN, Fawcett JW, McMahon SB (2002) Chondroitinase ABC promotes functional recovery after spinal cord injury. Nature 416:636-640.

Brittis PA, Canning DR, Silver J (1992) Chondroitin sulfate as a regulator of neuronal patterning in the retina. Science 255:733-736.

Bu J, Akhtar N, Nishiyama A (2001) Transient expression of the NG2 proteoglycan by a subpopulation of activated macrophages in an excitotoxic hippocampal lesion. Glia 34:296-310.

Bu J, Banki A, Wu Q, Nishiyama A (2004) Increased NG2+ glial cell proliferation and oligodendrocyte generation in the hypomyelinating mutant shiverer. Glia 48:51-63.

Chen MS, Huber AB, van der Haar ME, Frank M, Schnell L, Spillmann AA, Christ F, Schwab ME (2000) Nogo-A is a myelin-associated neurite outgrowth inhibitor and an antigen for monoclonal antibody IN-1. Nature 403:434-439.

Chen ZJ, Ughrin Y, Levine JM (2002a) Inhibition of axon growth by oligodendrocyte precursor cells. Mol Cell Neurosci 20:125-139.

Chen ZJ, Negra M, Levine A, Ughrin Y, Levine JM (2002b) Oligodendrocyte precursor cells: reactive cells that inhibit axon growth and regeneration. J Neurocytol 31:481-495.

Dawson MR, Polito A, Levine JM, Reynolds R (2003) NG2-expressing glial progenitor cells: an abundant and widespread population of cycling cells in the adult rat CNS. Mol Cell Neurosci 24:476-488.

de Castro Jr R, Tajrishi R, Claros J, Stallcup WB (2005) Differential responses of spinal axons to transection: influence of the NG2 proteoglycan. Exp Neurol 192:299-309.

Denis-Donini S, Glowinski J, Prochiantz A (1984) Glial heterogeneity may define the three-dimensional shape of mouse mesencephalic dopaminergic neurones. Nature 307:641-643.
Dou CL, Levine JM (1994) Inhibition of neurite growth by the NG2 chondroitin sulfate proteoglycan. J Neurosci 14:7616-7628.

Fallon JR (1985) Preferential outgrowth of central nervous system neurites on astrocytes and Schwann cells as compared with nonglial cells in vitro. J Cell Biol 100:198-207.

Fidler PS, Schuette K, Asher RA, Dobbertin A, Thornton SR, Calle-Patino Y, Muir E, Levine JM, Geller HM, Rogers JH, Faissner A, Fawcett JW (1999) Comparing astrocytic cell lines that are inhibitory or permissive for axon growth: the major axon-inhibitory proteoglycan is NG2. J Neurosci 19:8778-8788.

Fournier AE, GrandPre T, Strittmatter SM (2001) Identification of a receptor mediating Nogo-66 inhibition of axonal regeneration. Nature 409: 341-346.

Friedlander DR, Milev P, Karthikeyan L, Margolis RK, Margolis RU, Grumet M (1994) The neuronal chondroitin sulfate proteoglycan neurocan binds to the neural cell adhesion molecules Ng-CAM/L1/NILE and $\mathrm{N}-\mathrm{CAM}$, and inhibits neuronal adhesion and neurite outgrowth. J Cell Biol 125:669-680.

Gorgels TG (1991a) Outgrowth of the pyramidal tract in the rat cervical spinal cord: growth cone ultrastructure and guidance. J Comp Neurol 306:95-116.

Gorgels TG (1991b) Junctional specializations between growth cones and glia in the developing rat pyramidal tract: synapse-like contacts and invaginations. J Comp Neurol 306:117-128.

GrandPre T, Nakamura F, Vartanian T, Strittmatter SM (2000) Identification of the Nogo inhibitor of axon regeneration as a reticulon protein. Nature 403:439-444.

Grimpe B, Dong S, Doller C, Temple K, Malouf AT, Silver J (2002) The critical role of basement membrane-independent laminin gamma 1 chain during axon regeneration in the CNS. J Neurosci 22:3144-3160.

Haas K, Sin W-C, Javaherian A, Zheng L, Cline HT (2001) Single-cell electroporation for gene transfer in vivo. Neuron 29:583-591.

Hicks SP, D'Amato CJ (1968) Cell migrations to the isocortex in the rat. Anat Rec 160:619-634.

Hoke A, Silver J (1996) Proteoglycans and other repulsive molecules in glial boundaries during development and regeneration of the nervous system. Prog Brain Res 108:149-163.

Horner PJ, Power AE, Kempermann G, Kuhn HG, Palmer TD, Winkler J, Thal LJ, Gage FH (2000) Proliferation and differentiation of progenitor cells throughout the intact adult rat spinal cord. J Neurosci 20:2218-2228.

Jones LL, Yamaguchi Y, Stallcup WB, Tuszynski MH (2002) NG2 is a major chondroitin sulfate proteoglycan produced after spinal cord injury and is expressed by macrophages and oligodendrocyte progenitors. J Neurosci 22:2792-2803.

Jones LL, Sajed D, Tuszynski MH (2003) Axonal regeneration through regions of chondroitin sulfate proteoglycan deposition after spinal cord injury: a balance of permissiveness and inhibition. J Neurosci 23:9276-9288.

Kantor DB, Chivatakarn O, Peer KL, Oster SF, Inatani M, Hansen MJ, Flanagan JG, Yamaguchi Y, Sretavan DW, Giger RJ, Kolodkin AL (2004) Semaphorin $5 \mathrm{~A}$ is a bifunctional axon guidance cue regulated by heparan and chondroitin sulfate proteoglycans. Neuron 44:961-975.

Koester SE, O'Leary DD (1994) Axons of early generated neurons in cingulate cortex pioneer the corpus callosum. J Neurosci 14:6608-6620.

Kottis V, Thibault P, Mikol D, Xiao ZC, Zhang R, Dergham P, Braun PE (2002) Oligodendrocyte-myelin glycoprotein (OMgp) is an inhibitor of neurite outgrowth. J Neurochem 82:1566-1569.

Levine JM (1994) Increased expression of the NG2 chondroitin-sulfate proteoglycan after brain injury. J Neurosci 14:4716-4730.

Levine JM, Stallcup WB (1987) Plasticity of developing cerebellar cells in vitro studied with antibodies against the NG2 antigen. J Neurosci 7:2721-2731.

Levine JM, Reynolds R, Fawcett JW (2001) The oligodendrocyte precursor cell in health and disease. Trends Neurosci 24:39-47.

Lin SC, Huck JH, Roberts JD, Macklin WB, Somogyi P, Bergles DE (2005) Climbing fiber innervation of NG2-expressing glia in the mammalian cerebellum. Neuron 46:773-785.

Liu BP, Fournier A, GrandPre T, Strittmatter SM (2002) Myelin-associated glycoprotein as a functional ligand for the Nogo-66 receptor. Science 297:1190-1193.

Mason CA, Wang LC (1997) Growth cone form is behavior-specific and, 
consequently, position-specific along the retinal axon pathway. J Neurosci $17: 1086-1100$.

McCarthy KD, de Vellis J (1980) Preparation of separate astroglial and oligodendroglial cell cultures from rat cerebral tissue. J Cell Biol 85:890-902.

McKerracher L, David S, Jackson DL, Kottis V, Dunn RJ, Braun PE (1994) Identification of myelin-associated glycoprotein as a major myelinderived inhibitor of neurite growth. Neuron 13:805-811.

McLean IW, Nakane PK (1974) Periodate-lysine-paraformaldehyde fixative. A new fixation for immunoelectron microscopy. J Histochem Cytochem 22:1077-1083.

Milev P, Friedlander DR, Sakurai T, Karthikeyan L, Flad M, Margolis RK, Grumet M, Margolis RU (1994) Interactions of the chondroitin sulfate proteoglycan phosphacan, the extracellular domain of a receptor-type protein tyrosine phosphatase, with neurons, glia, and neural cell adhesion molecules. J Cell Biol 127:1703-1715.

Moon LD, Asher RA, Rhodes KE, Fawcett JW (2001) Regeneration of CNS axons back to their target following treatment of adult rat brain with chondroitinase ABC. Nat Neurosci 4:465-466.

Morgenstern DA, Asher RA, Fawcett JW (2002) Chondroitin sulphate proteoglycans in the CNS injury response. Prog Brain Res 137:313-332.

Mukhopadhyay G, Doherty P, Walsh FS, Crocker PR, Filbin MT (1994) A novel role for myelin-associated glycoprotein as an inhibitor of axonal regeneration. Neuron 13:757-767.

Neugebauer KM, Tomaselli KJ, Lilien J, Reichardt LF (1988) N-cadherin, NCAM, and integrins promote retinal neurite outgrowth on astrocytes in vitro. J Cell Biol 107:1177-1187.

Niehaus A, Stegmuller J, Diers-Fenger M, Trotter J (1999) Cell-surface glycoprotein of oligodendrocyte progenitors involved in migration. J Neurosci 19:4948-4961.

Nishiyama A, Dahlin KJ, Prince JT, Johnstone SR, Stallcup WB (1991) The primary structure of NG2, a novel membrane-spanning proteoglycan. J Cell Biol 114:359-371.

Nishiyama A, Lin XH, Giese N, Heldin CH, Stallcup WB (1996a) Colocalization of NG2 proteoglycan and PDGF alpha-receptor on O2A progenitor cells in the developing rat brain. J Neurosci Res 43:299-314.

Nishiyama A, Lin XH, Giese N, Heldin CH, Stallcup WB (1996b) Interaction between NG2 proteoglycan and PDGF alpha-receptor on O2A progenitor cells is required for optimal response to PDGF. J Neurosci Res 43:315-330.

Nishiyama A, Watanabe M, Yang Z, Bu J (2002) Identity, distribution, and development of polydendrocytes: NG2-expressing glial cells. J Neurocytol 31:437-455.

Noble M, Fok-Seang J, Cohen J (1984) Glia are a unique substrate for the in vitro growth of central nervous system neurons. J Neurosci 4:1892-1903.

Oakley RA, Tosney KW (1991) Peanut agglutinin and chondroitin-6-sulfate are molecular markers for tissues that act as barriers to axon advance in the avian embryo. Dev Biol 147:187-206.

Okada A, Lansford R, Weimann JM, Fraser SE, McConnell SK (1999) Imaging cells in the developing nervous system with retrovirus expressing modified green fluorescent protein. Exp Neurol 156:394-406.

Ozaki HS, Wahlsten D (1992) Prenatal formation of the normal mouse corpus callosum: a quantitative study with carbocyanine dyes. J Comp Neurol 323:81-90.

Povlishock JT (1976) The fine structure of the axons and growth cones of the human fetal cerebral cortex. Brain Res 114:379-379i.

Schneider S, Bosse F, D’Urso D, Muller H, Sereda MW, Nave K, Niehaus A,
Kempf T, Schnolzer M, Trotter J (2001) The AN2 protein is a novel marker for the Schwann cell lineage expressed by immature and nonmyelinating Schwann cells. J Neurosci 21:920-933.

Shearer MC, Niclou SP, Brown D, Asher RA, Holtmaat AJ, Levine JM, Verhaagen J, Fawcett JW (2003) The astrocyte/meningeal cell interface is a barrier to neurite outgrowth which can be overcome by manipulation of inhibitory molecules or axonal signalling pathways. Mol Cell Neurosci 24:913-925.

Shu T, Richards LJ (2001) Cortical axon guidance by the glial wedge during the development of the corpus callosum. J Neurosci 21:2749-2758.

Shu T, Puche AC, Richards LJ (2003) Development of midline glial populations at the corticoseptal boundary. J Neurobiol 57:81-94.

Silver J, Miller JH (2004) Regeneraation beyond the glial scar. Nat Rev Neurosci 5:146-156.

Silver J, Lorenz SE, Wahlsten D, Coughlin J (1982) Axonal guidance during development of the great cerebral commissures: descriptive and experimental studies, in vivo, on the role of preformed glial pathways. J Comp Neurol 210:10-29.

Silver J, Edwards MA, Levitt P (1993) Immunocytochemical demonstration of early appearing astroglial structures that form boundaries and pathways along axon tracts in the fetal brain. J Comp Neurol 328:415-436.

Smith GM, Miller RH, Silver J (1986) Changing role of forebrain astrocytes during development, regenerative failure, and induced regeneration upon transplantation. J Comp Neurol 251:23-43.

Smith GM, Rutishauser U, Silver J, Miller RH (1990) Maturation of astrocytes in vitro alters the extent and molecular basis of neurite outgrowth. Dev Biol 138:377-390.

Snow DM, Lemmon V, Carrino DA, Caplan AI, Silver J (1990) Sulfated proteoglycans in astroglial barriers inhibit neurite outgrowth in vitro. Exp Neurol 109:111-130.

Stallcup WB (2002) The NG2 proteoglycan: past insights and future prospects. J Neurocytol 31:423-435.

Stallcup WB, Beasley L (1987) Bipotential glial precursor cells of the optic nerve express the NG2 proteoglycan. J Neurosci 7:2737-2744.

Tang X, Davies JE, Davies SJ (2003) Changes in distribution, cell associations, and protein expression levels of NG2, neurocan, phosphacan, brevican, versican V2, and tenascin-C during acute to chronic maturation of spinal cord scar tissue. J Neurosci Res 71:427-444.

Tom VJ, Doller CM, Malouf AT, Silver J (2004) Astrocyte-associated fibronectin is critical for axonal regeneration in adult white matter. J Neurosci 24:9282-9290.

Ughrin YM, Chen ZJ, Levine JM (2003) Multiple regions of the NG2 proteoglycan inhibit neurite growth and induce growth cone collapse. J Neurosci 23:175-186.

Wang KC, Koprivica V, Kim JA, Sivasankaran R, Guo Y, Neve RL, He Z (2002) Oligodendrocyte-myelin glycoprotein is a Nogo receptor ligand that inhibits neurite outgrowth. Nature 417:941-944.

Watanabe M, Toyama Y, Nishiyama A (2002) Differentiation of proliferated NG2-positive glial progenitor cells in a remyelinating lesion. J Neurosci Res 69:826-836.

Yang Z, Watanabe M, Nishiyama A (2005) Optimization of oligodendrocyte progenitor cell culture method for enhanced survival. J Neurosci Methods 149:50-56.

Yu JY, DeRuiter SL, Turner DL (2002) RNA interference by expression of short-interfering RNAs and hairpin RNAs in mammalian cells. Proc Natl Acad Sci USA 99:6047-6052. 